\author{
MARINA APTEKMAN \\ Tufts University (Medford, MA, USA) \\ iD \\ ORCID 0000-0002-5869-344X
}

\title{
To the Holy Land and Back: The Opposition of Two Zions in Russian-Jewish Literature of the 1930s
}

Do Ziemi Świętej i z powrotem: konflikt „dwóch Syjonów” w literaturze rosyjsko-żydowskiej lat 30. XX wieku

Streszczenie: W roku 1934 rząd radziecki podjął decyzję o utworzeniu Żydowskiego Obwodu Autonomicznego Birobidżan w odległym zakątku Dalekiego Wschodu. Ogólna koncepcja ŻOA nawiązywała zarówno do propagandy radzieckiej, jak i szerzonej w Palestynie przez osadników żydowskich. Pisarzom żydowskim w ZSRR władze nieoczekiwanie zezwoliły wówczas na tworzenie tekstów promujących i rozwijających tematykę żydowską, jak również opisujących żydowskich osadników w Palestynie. Spośród wszystkich utworów poświęconych zestawieniu ŻOA i Palestyny na wyróżnienie zasługuje powieść Siemiona Götha i pamiętniki Marka Egarta — jedyne beletryzowane biografie dotyczące Palestyny w języku rosyjskim. Artykuł ma na celu zbadanie obecności i interpretacji palestyńskiego projektu w literaturze rosyjskiej lat 30. ubiegłego stulecia, analizę czynników ideologicznych i kulturowych, które przyczyniły się do powstania wspomnianych utworów oraz uzasadnienie ich znaczenia dla historii kultury Żydów radzieckich.

Słowa kluczowe: Żydowski Obwód Autonomiczny, Birobidżan, rosyjska i radziecka literatura żydowska, Palestyna, samoidentyfikacja, travelogue, osadnicy, Göth, Egart

\section{В святую землю и обратно: конфликт «двух Сионов» в русско-еврейской литературе 1930-ых годов}

Резюме: В 1934 году советское правительство приняло решение о создании Еврейской автономной области Биробиджан в отдаленном регионе Дальнего Востока. Основная идеология ЕАО в то время сильно перекликалась с советской пропагандистской машиной, но одновременно отражала пропаганду, которую применяли в Палестине сионистские поселенцы. При поддержке правительства еврейским писателям в СССР неожиданно разрешили создавать произведения, которые продвигали и развивали еврейские образы, но также обсуждали жизнь Палестинских еврейских поселенцев. Из всех произведений, посвященных противостоянию ЕОА и Палестины, можно выделить роман Семена Гехтина и мемуары Марка Эгарта — единственные беллетризованные биографии о Палестине на русском языке. Цель статьи - исследовать репрезентацию и интерпретацию Палестинского проекта в советской литературе 30-ых годов, проанализировать идеологические и культурные факторы, которые привели к созданию этих двух произведений, и обосновать их важное значение в истории советской еврейской культуры.

Ключевые слова: Еврейская автономная область, Биробиджан, еврейская русская и советская литература, Палестина, само-идентификация, травелог, поселенцы, Гехт, Эгарт 
In 1932 the Soviet magazine "October" published a novel entitled The Scorched Land (Опалённая земля), by Mark Egart. The novel was reprinted as a separate publication in 1932-1933 and received relatively wide critical acclaim. In 1936 it was followed by another work, A Steamboat Goes to Jaffa and Back (Parokhod idet $v$ laffu i obratno) by writer and Jewish Russian-speaking journalist Semyon Gekht. Both novels were written by authors who resided in Moscow and belonged to the Russian-speaking cultural elite. Both written according to the rigidly defined criteria of Socialist Realism and employing much of the imagery and style of a typical Soviet production novel, these two works, however, dealt with subjects not characteristic in the least of a typical Soviet work: they discussed the details of life, successes and failures of RussianJewish settlers in Palestine.

Raising the subject of Jewish settlement in Palestine in Soviet works of that historical period has not been accidental. It emerged most probably primarily because of the Soviet decision to create the Jewish Autonomous Region, and in so doing, to establish an opposition between the JAR and Palestine. Gehkt's and Egart's novels were produced to either solely criticize the Palestinian settlements and discuss the disillusionment of Russian halutzim, (as does Egart's novel), or share with the readers the failures of the yishuv as contrasted to the successes of the new Soviet territorial projects (as seen in Geht's work). The outcome was, however, quite different. The Scorched Land and The Steamboat Goes to Jaffa and Back has become the only Russian-language fictionalized biographies about Palestine that ever appeared in the Soviet mainstream. In spite of a strongly negative interpretation of events, both the authors, unintentionally or probably even on purpose, manage to bring to the reader many authentic details of the reality of the yishuv in the 1920s and 1930s, details that allow the interested reader to learn about the everyday life of the halutzim, their troubles and achievements.

Throughout most of the 1920s and early 1930s the Soviet government supported secular Jewish culture, and largely promoted the involvement of Jews in all aspects of social and political life. By contrast, the future of the Jewish settlement of Palestine was uncertain. Surrounded by a hostile Arab population and suffering from a lack of support from British government, the agricultural project in Palestine seemed doomed to many of those Jews who were looking to build their own homeland. Due to stiff Arab opposition, Britain restricted Jewish immigration and prohibited Jews in Palestine from buying more land outside their 
existing settlements. British rule also distinguished between poor and rich Jews: Annual quotas were put in place as to how many Jews could immigrate, although Jews possessing a large sum of money were allowed to enter the country freely. Such conditions resulted in the rise of a cynical attitude toward the future of the yishuv, primarily in Socialist Jewish circles, which started to view Zionism as a short-lived experiment'.

In May 1934 the Soviet government established the Jewish Autonomous Region (JAR) in a remote and sparsely populated area of taiga in the Russian Far East near the Chinese border. The institution of the Jewish Autonomous Region was not the first incident to raise the question of the opposition between two Jewish homelands - the Red Zion in the USSR and the Blue and White Zion in the Middle East. It was preceded by the decision to create Jewish agricultural colonies in Crimea, a project which at first was relatively widely popularized in Soviet media in 1920s yet stagnated by the $1930 \mathrm{~s}^{2}$. However, the creation of the JAR, in a ways much stronger that the Crimean project, revived the territorial wars and ideological competition between Palestine and the Diaspora that had arisen as early as at the end of the nineteenth century and focused on the issues of land, language, and autonomy, and the role that they played in the creation of Jewish identity. In contrast to the Crimean project, the ideologists of the JAR emphasized the fact that the region would be regarded as an autonomously governed social unit, a true "Jewish state", with Yiddish as an official language, Yiddish education, Yiddish media and culture, and Jewish administration. This emphasis created an opposition between the JAR and Hebrew-speaking, "bourgeois", colonial Palestine. In 1928, as the JAR project was beginning, Russian newspapers circulated numerous articles directly focused on the opposition between the new project and Palestine. Most of the articles purported to illuminate the conditions of life in Zion. One of them claimed that "Poor Jews from the capitalist world, who are now desperately waiting for an entry visa to Palestine, cannot even imagine what hardships await them there: unemployment, low pay rates, constant abuse from Arab peasants and harassment from British officials. The Jewish project in Palestine is doomed"3.

1 For example, in Harbin, Dr. Kauffman published in his newsletter Jewish Life, that, "News from Palestine...interested no one". М. Зозуля, Межпартийная полемика в харбинской еврейской общине, in: Ber B. Kotlerman (ed.), Mizrekh: Jewish Studies in the Far East, Peter Lang, Frankfut am Main 2011, p. 106.

2 For more on Crimean project, see: A. Kagedan, Soviet Zion: The Quest for a Russian Jewish Homeland, St. Martin's Press, New York 1994.

3 Е. Штейнберг, Сионисты в конфликте с Англией, “Известия", 29.10.1930. 
By contrast, all articles highlighted the fact that the "future Jewish Region will serve as a symbol of Soviet Jewish statehood"4. In 1930 Isaak Sudarsky, a Jewish journalist from Ukraine, produced a pamphlet, called Birobidzhan and Palestina. Sudarsky explains in the short preface to the book that "since Zionists dismiss the idea of Birobidzhan by calling on Jews to help them to build a Jewish pseudo-utopian state in Palestine, it is our goal to warn Jewish workers against the phony tactics of their Zionists friends" ${ }^{\prime \prime}$. He argues his case with facts and numbers. In Palestine, for example, he notes that 60.9 percent of land is ill-suited for agriculture, and only 3 percent is actively cultivated. By contrast, the JAR provides 400,000 square hectares of agricultural land that can immediately host as many as 50,000 families ${ }^{6}$. He adds that Palestinian soil lacks minerals, while that of the JAR contains coal, marble, and gold. Therefore, he concludes, while "Zionists use ideology to lure the Jewish proletariat into the holy land, Birobidzhan does not require any ideological support. Its climate, rich soils, and prominent agricultural potential speak for themselves"7.

According to Sudarsky, "Palestine's main problem is that it has three owners, the Brits, the Arabs and the Jews" ${ }^{\prime \prime}$. As he argues, since Arabs hold to $33 \%$ of land while Jews own a mere $3 \%$, the only option for the Jewish settler to obtain the land is to buy it from Arabs. Most land in Palestine is in the hands of Arab landlords; however, for centuries this land was cultivated by Arab peasants, the fellahins. By buying this land from bankrupt landlords the Zionists deprive the peasants of their means of supporting themselves and their families. They behave like colonizers; and the fate of the poor fellahins interests them no more that it interests the rich landlord. This rapacious policy raises anti-Jewish sentiments among the Arabs and creates a situation in which the native Arab population regards Jewish settlers as enemies and encroachers. The peasants resist in bloody strikes; the Zionists require the police to stop and prevent those attacks, and, as a result, a Jew in Palestine would always have to behave as an oppressor of the poor, and would always fear for his life and his property.

Sudarsky concludes by stating that "Jewish Palestine has no future, because it is founded on one nation oppressing the other. By contrast with Palestine, Birobidzhan is founded on the

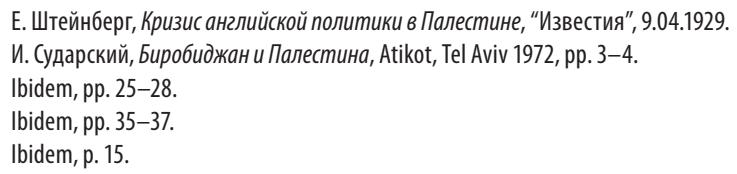


friendship between all nationalities" ${ }^{\prime \prime}$. In contrast to the invasive nature of Zionism, the Soviet state presented the construction of the JAR as an all-Soviet project, where Jews and non-Jews together were called and mobilized "to develop as fast as possible this extremely rich region"10.

To support and nourish the Palestine-JAR opposition, the Soviet government needed either to provide proof of a significant immigration from the Holy Land, or at least popularize a successful media image of it. The main support for the Birobidzhan project came from the members of the multi-national Communist Party of Palestine (PCP), which its Russian-speaking Jewish opponents often called by the insulting nickname "pugs"-MOPSy in Russian, a term that directly translated the Hebrew abbreviation for the party name, Mifleget-ha-Poalei-ha-Zion"1. As a result of their efforts about 150 people decided to leave. In an open letter published in a socialist newspaper Davar on August 17, 1932, a group of communists moving to Birobidzhan declared the following:

We, the group of the first immigrants to Birobidzhan, leave the country not only because Zionism has not been able to solve the problem of poverty of the Jewish masses, but also due to the fact that Zionism ... is a black reactionary force... We're going to Birobidzhan, united by the firm belief that together with the other 160 million of our brothers and with the help of the government, led by the working class, we will be able to realize the dream of uniting the broad strata of the Jewish masses around the idea of building a socialist homeland ${ }^{12}$.

Yet, as early as in 1930, "Davar" produced a series of articles about the Jewish Autonomous Region by a worker who was able to return ${ }^{13}$. It is hard to say how truthful his writings were and in

9 Ibidem, p. 36-38.

10 С. Диманштейн, Еврейская автономная область - детище октябрьской революции, "Революция и национальности" 1934, no 6, р. 21. Between 1933 and 1936 the only Yiddish newspaper of the region, "The Star of Birobidzhan", constantly published the letters from famous Soviet non-Jews, such as the Arctic pilot Valery Chkalov and a famous worker Alexei Stakhanov, which supported and praised "the Jewish efforts to change the faraway taiga into a blooming and striving Communist region". (The Open Letter of the Heroes of the Soviet Union, V. P. Chkalov, G. F. Baidukov, and A. V. Beliakov to the Jewish settlers in the JAR, "Birobidzhaner Shtern" 18.08.1936. A similar letter from the crew of the Arctic icebreaker Cheliuskin appeared in the same newspaper on 07.05.1935. The letter from Stahanov was published on 03.06.1936).

11 As recent research has shown, NKVD had sent secret agents to PCP to promote the repatriation propaganda, disguised as the activities of The Association of Friendship with the USSR. The head of the committee for repatriation, Konstantin Weiss, was a Soviet spy, who worked under a pseudonym Avigdor, firstly in Egypt and then in Palestine. He later returned to the USSR, and, together with many others, perished in the purges of 1937. See: S. Dotan, Biroidzhan kealternativa le Erts Yisrael, "Ha-Uma” 1993, no 4, pp. 209-214.)

12 "Davar", 17.08.1932, p. 4.

13 The series was published anonymously, but recently Israeli scholar Shmuel Dotan was able to trace the author, Isroel Levin, who turned out to be one of the members of PCP. An interesting comparison of the 
what measure they were designed to excuse his abandonment of the project, but his stories certainly played a role in the colonists' reluctance to continue to move to Birobidzhan ${ }^{14}$. Moreover, the PCP soon realized that an increasing flow of colonists would diminish the overall numbers of its Jewish members remaining in Palestine and therefore, weaken the party's position in the yishuv ${ }^{15}$. Those who left settled mostly in the ICOR commune, a multi-national collective farm for foreigners. An anecdote tells the story of Lazar Kaganovich's visit to the ICOR settlement in 1936. When he asked the settlers about their needs and wishes, a lady complained that in Palestine her toddler son was able to eat a banana each morning for breakfast, a habit that he now greatly missed. Kaganovich replied with a promise that in a few years the settlers would be able to start growing bananas ${ }^{16}$. The farm existed until the end of 1930s, when most of its members had either left the region voluntarily or had been arrested, and then merged with a neighboring Ukrainian collective. It seems that no bananas have ever been produced in its orchards.

In line with the growing importance of the role of industry in Soviet ideology, Sudarsky emphasizes that agriculture alone would not be sufficient to create a successful economy for a state or a region. He claims that Palestine is predestined to fail due to its lack of heavy industry, because "to a national economy industry is of a higher priority than agriculture"17. By contrast with the Crimea project that was a solely agricultural venture, he insists that the JAR has all the potential to become an industrial center. In 1937, Sudarsky, who actually never visited Birobidzhan, would be arrested and executed and his book would fall into oblivion. However, this pamphlet has formulated the key postulates that would later be repeated in most Soviet texts dedicated to the discussion of the ideological struggle between the JAR and Palestine. In a way, this tiny book has summarized all those stereotypical negative images of the yishuv that one can later see in all major Soviet works that would describe the failures of life in Jewish Palestine.

Semyon Geht's A Steamboat Goes to Jaffa and Back opposes the misfortunes of the main character in Palestine while comparing

two Jewish "states" can be also seen in D. Soyer, Abraham Cahan's Travels in Jewish Homelands: Palestine in 1925 and the Soviet Union in 1927, in: G. Estraikh and M. Krutikov (eds.), Yiddish and the Left, Legenda, New York 2000, pp. 56-79.

14 S. Dotan, Adumin: Ha-Miflagah ha-komunistit be-Erets-Yisrael, Shevna-ha-Sofer, Kefar-Saba 1991, pp. 253, 561.

15 Nati Cantorovich, Bauhaus in Birobidzhan, (review), in: B. Kotlerman (ed.), Mizrekh:Jewish Studies in the Far East, p. 208.

16 GAEA0, f. 3, op. 5.1, p. 12.

17 И. Сударский, Биробиджан и Палестина..., р. 39. 
his life to the positive life of settlers in the JAR. By contrast, none of the events in Mark Egart's The Scorched Land happens in the Soviet Far East. The plot takes places in either Pale of Settlement, Poland of Palestine. Yet, in our view, these works should still be regarded together. First of all, as stated above, even if Egart's novel does not discuss the Soviet settlements, it has been published, in our view, precisely in link with the starting campaign to support the Far Eastern project by presenting the Jewish Palestine in negative light. Yet, at the same time, although the essential task of Geht's work has been to familiarize the readers with Birobidzhan, most part of the plot primarily concentrates on protagonist's life in Palestine. Thus, it is indeed Palestinian yishuv and not the Jewish Autonomous Region that serve as primarily settings for both works, and as such, they remain the only existing mainstream Soviet novels that allow the interested Russian reader visualize the life halutzim life in 1930s.

Both novels are first-person narrations ${ }^{18}$. However, by contrast with Gekht, who had never visited the Holy Land and who based his description of the settlers' lives primarily on literary memoirs or recollections of his acquaintances, Mark Egart immigrated to Palestine in 1923 as a part of the ha-Halutz movement, and spent approximately four years there. Again, in contrast to Gekht, he never visited the JAR. In Palestine, Egart worked in an agricultural settlement, yet gradually became disillusioned, started sympathizing with the PCP, and eventually decided to return to the USSR ${ }^{19}$. Maxim Shrayer argues that "Egart's novel owed its original publication in one of the leading Soviet journals to the sheer power of its narrative voice, the style of its prose, and its exotic subject matter"20. However, as noted before, the year of publication suggests a strong link with a growing colonization campaign and the peak of propaganda relating to the JAR. A critical account of the struggles and miseries of an immigrant in the Holy Land certainly worked to support Soviet anti-Zionist politics and prove the case for repatriation.

Semeon Gekht was born in Odessa. In the 1920s he moved to Moscow, worked as a newspaper sand writer, participated in an infamous writers' trip to the White Sea Channel construction site,

18 For a detailed biography of Egart, see: M. Shrayer, Mark Egart and the Legacy of His Soviet Novel about Halutzim, "On the Jewish Street" 2011, no 1, pp. 1-14.

19 As Mikhail Weisskoph correctly noted, Egart was never arrested or persecuted despite the Zionist chapter of his biography, which, in the general atmosphere of 1930 s, looks rather suspicious and raises the possibility that he was a secret NKVD agent. М. Вайскопф, Образ героини в анти-сионистском романе М. Эгарта "Опалённая земля", in: E. Nosenko (ed.), Израиль глазами русских: культура и идентичность, Natalis, Москва 2008, p. 365.

20 M. Shrayer, Mark Egart..., p. 6. 
published short stories and short novels, and was imprisoned in the mid-1940s. In 1937 he published a number of articles and short stories firstly about the Crimean settlements and then about Birobidzhan. In the late 1920s as a newspaper correspondent he visited Jewish settlements in Crimea ${ }^{21}$. The result of the trip was a trilogy, called Efim Koluzhny from Smidovichi, which appeared in 1930-1931 in the popular literary almanac "Roman-Gazeta"22. The novel, based primarily on articles and sketches previously published in "Izvestiia", describes the life of a Jewish teenager at a collective farm in the Crimea. Gekht's coverage of the Crimea probably explains why he was chosen by the editors of "Izvestiia" to cover the topic of the settlements in the Far East as well. In 1930 Gekht visited the region, and between 1930 and 1937 he published multiple articles about the settlers ${ }^{23}$. In 1936 Gekht was chosen to accompany an American expedition funded by AgroJoint to the JAR. He published the accounts of his trip in the article Americans in Biro-Bidzhan, in "Izvestiia" in 193724. Gekht produced The Steamboat Goes to Jaffa and Back in 1936. The book was created most probably as an ideological assignment and was based on his previous articles and travelogues ${ }^{25}$.

The title of the novel is not accidental. In the 1920s the image of the steamboat had been perpetually used in media articles about emigrants and repatriates. In 1926 an article in "Pravda" mentioned that the repatriation of ex-Russian Jews was at its peak, and that the "Soviet government is currently discussing the possibility of the establishment of a special agency in Jaffa that would offer the repatriating Jews a return ticket on the steamships of the Soviet Merchant Navy that return to USSR from the Middle East" ${ }^{226}$. According to Soviet ideology, the repatriation of Jews from Palestine was symbolic proof of the fact that in the new social order established by Bolsheviks, the Jews chose Communism over Zionism. As early as in September 1923, "Pravda" published an essay called The Seekers of Happiness, about Jewish emigrants who "are going to their non-existent invisible dreamland, leaving behind what they believe to be mythological Egypt". The Jewish

\footnotetext{
21 See: H. Murav, Music from a Speeding Train, Stanford University Press, Stanford 2011.

22 RGALI, f. 2800, op. 1, d. 62.

3 Ibidem.

24 С. Гехт, Американцы в Биробиджане, “Известия", 06.08.1936.

25 For example, one of the main characters, an American agricultural specialist from Utah, Benjamin Brown, had appeared as a protagonist in the article Americans in Birobidzhan. A negative protagonist, the old and repulsive rabbi Akiva, had already been depicted in a short story Life after Death, published in the almanac "30 Days" and also partially in "Izvestiia" in 1933. С. Гехт, Жизнь после смерти, "30 дней" 1933, nо 6, pp. 12-18.

26 Палестина под крылышком английского сионизма, "Правда", 07.07.1926.
} 
myth of Exodus is constantly subverted in the essay. Similar imagery and ideology is also dominant in The Scorched Land. As Israeli critic Mikhail Weisskoph describes it:

A Zionist idealist, who is leaving the "Russian Egypt" for the land of heavenly eternal spring, the land of national liberation of the Jewish people, quickly comes to the conclusion that he was badly mistaken, and now he sees everything in the darkest colors. Suddenly his new land, its dead sands and hard work, appears to be the land of slavery, while his original motherland is suddenly regarded in the most alluring light ${ }^{27}$.

Same metaphor, as French scholar Boris Czerny argues, is broadly employed in Gekht's novel. Russian Jews leave for Palestine believing that they leave behind a country of misery and slavery, their metaphorical Egypt, and, as their mythical ancestors did, they return to the holy land of their forefathers ${ }^{28}$. Yet they soon realize that the Zionist Palestine is the opposite of the genuine Holy Land. Palestine, not Soviet Russia, is the true Egypt. The metaphors of Haggadah are hidden throughout both texts. The detail that mostly strikes the reader throughout both Egart's and Gekht's novels is that all characters at some point of their lives in Palestine have to work in extremely hard and underpaid conditions at a brick factory - a detail that immediately reminds the reader of Jewish slaves in Egypt working on brick production for the pyramids. The name of the brick factory boss in The Scorched Land is called Moshe, and he pays his workers in Egyptian cash. Jews in Palestine are humiliated, exploited, and harassed by their rich bosses, by earlier immigrants who therefore regard themselves of a higher status, and by their neighboring Arab workers. A Jew in Palestine is never free. The true Exodus is not an Exodus from Egypt to Israel; it is a flee from Israel to the USSR:

И тогда Авивит, сидя над «биркой» - водой, отдирает наклейку с бочонка и читает зачем-то вслух: «Эрэ-сэ-фэ-сэр... Новороссийский цементный завод... Областной совет народного хозяйства... Хозяйство-о, - повторяет она ещё раз и глядит на меркнущие пески». «Мы уйдём отсюда, - подхватывает её мысли Лазарь Даян. - Мы уйдем туда, где нет комбинаторов и ловкачей» ${ }^{29}$.

The plot of The Steamboat Goes to Jaffa and Back is based on the opposition between the personal narration of the implied author,

27 М. Вайскопф, Красное платьище..., pp. 364-76, pp. 365-66.

28 B. Czerny, Le Voyageur et l'émigré. Le motif de la sortie d'Egypte dans la littérature russe des années 19201930, "Cahiers du Monde Russe" 2011, Vol. 52, No. 4.

29 М. Эгарт, Опалённая земля, Художественная литература, Москва 1933, vol. 1, p. 73. 
who, as a part of an American expedition, visits the JAR, and the biography of his friend from Odessa, Alexander Gordon, who had left for Palestineshortly after the revolution. Gordon initially derides communist ideas and believes that the social and political changes in Russia would not improve the fate of Russian Jews. He regards communism as a temptation that leads Jews away from their only true ideology, Zionism. Similarly, the hero of Egart's novel, young Zionist Lazar Dayan, initially possesses a fierce hatred of his native Russia and Ukraine that has not been altered either by the Bolshevik Revolution or the Civil War. He feels a contemptuous indifference toward the Revolution and wholeheartedly supports the militant ideas of Zeev Jabotinsky.

Both Gordon and Dayan despise the world of the shtetl. They hate tradition and religion with a fierce hatred full of anti-Semitic stereotypes. Gordon believes that synagogues smell of decay and death. Lazar recalls that his father, who spent all his free time in prayer, was scared of the light of sun and always smelled of onion and garlic. While hiding in a cell from pogromists, his father complained that the presence of women in the same room made him feel dirty, and as a result of his loud moans the Cossacks found the hideout. Dayan comes from a small Jewish town Gnilopol (Rotten Town in Russian) called as such for being built on the foul swampy river ${ }^{30}$. He compares the houses of his shtetl to blind, mute, and handicapped midgets. Gordon remembers the first pogrom that he witnessed as a child and the fierce humiliation of the realization of everyone's passivity and apathy in face of the danger. However, while condemning the tradition and its followers, both authors also discuss in great detail the protagonists' gradual disillusionment with Zionist ideas and demonstrate that Jerusalem is no better than the shtetl. Geht's description of the Old City, with its "handicapped crooked" houses, "the smell of rot", and "ugly disfigured old Jews with long beards" echoes that of Gnilopol. Just as in the old world, a young Jerusalem girl is forced to marry an elderly rich rabbi against her will in a marriage arranged by a matchmaker. The Jewish holy places are shown

${ }^{30}$ The name is a typical shtetl name for Jewish literary tradition. Consider, for example, Mendele's Gnilopyatovke. However, Weisskoph has interestingly suggested that a verbal game between gnil'i glina (in this context, mud, but also clay in Russian) implies that the name of the town can be regarded as a mystical metaphor. As Weisskoph notes, Lazar hopes that in Palestine he can undergo not only a physical, but also a metaphysical spiritual transformation. As told in the Old Testament, God created mankind from mud. The protagonist believes that embracing working on land (adama in Hebrew) in Palestine would help him to make the transformation from an old Jew shaped from the malodorous and foul mud of a shtetl into a New Adam, created from the healthy soil of his newly obtained Biblical homeland. (M. Вайскопф, Красное Платьище..., р. 369.) 
as an area of decay, of old age and death that appeal only to old squalid Talmudists. At the same time both protagonists become disillusioned with the ideas of modern Zionism. After a lot of hardships and miseries both Dayan and Gordon return to the USSR. Both authors proclaim one evident message: in spite of their character's aspirations, Zionist Palestine is by no means able to transform their old Jewish nature. The modern Holy Land is ruled in the same way as the old world of the shtetl, that is, by money, personal connections, and ethnic hatred.

Yet, while both authors' hate of shtetl seems rather genuine, their descriptions of Palestine are indefinitely ambiguous. For example, Gekht broadly employs the models of grotesque to intensify the feeling of decay and degeneration of Jerusalem ${ }^{31}$. Surprisingly the outcome of such technique works opposite to the publishers' intentions. A reader can easily noticed that the novel is composed in two evidently different styles. The chapters that present Palestine, especially Jerusalem, are written in a vivid, grotesque and hyperbolic fashion that deeply engage the reader, while the parts describing the life in the JAR employ the typical bland and boring style and language of Socialist Realism. As a result, the reader's attention is continuously turning to those pages that seemingly condemn Judaism and Zionism away from the chapters that praise the Soviet achievements. Even Soviet criticism noticed the weakness of Gekht's bland style in his descriptions of the settlers' lives in the JAR. A review published in "Literaturnaia Gazeta" in 1937 accused the author of inexpressive language, condemning his writing as being featureless and nondescript. Similarly, the accounts of Jewish exploitation of Arabs and the characters' miseries at the brick factories of Tel Aviv in Egart's novel are similarly undeveloped by contrast with extremely vivid descriptions of the nature of Palestine, its skies and orange groves, the sound of the Mediterranean sea, the aroma of bread on the streets of Jerusalem, the taste of a ripe tomato in a settler's hut, the howling of wind behind the tent, the sounds, the smells, and the colors. Boris Czerny even argues that Gekht "intentionally made the details of Palestinian reality much more vivid than that of Birobidzhan, thus turning the book into a secret code for those

31 Harriet Murav has recently demonstrated that such technique was widely used in Gekht's other writings and most probably originated from the works of his literary teachers Markish and Babel. As she notes, "Bodies swollen with disease and bursting with alien desires of the past litter Markish and Babel's texts. Their use of grotesque, repetition and hyperbole, together with intertexts from traditional mourning literature, undermines the discipline of the new revolutionary order... the... works of Gekht share a... similar set of narrative devices". H. Murav, Music from a Speeding Train. .., p. 48. 
who would like to read 'between the lines' and learn about life in Palestine"132.

Thus, we can state, that, although, by contrast with Egart's, Gekht's narrative does not solely concentrate on Palestine but on the contrast between the two Zions, still the plot development of both novels is revolving around the life in the yishuv. Both novels seem to be preoccupied by the question if indeed Palestine can succeed to create a new Jew, and both arrive to a solution that it cannot. Both Gekht and Egart believe that in order to create a new type of a Jew, liberated from its miserable past, one should completely and wholeheartedly destroy any trace of what had been called the tradition. Palestine, being a spiritual center of Judaism, will always hold a Jew back to its roots, wherefore it will not allow a Jew to break all ties with its religious heritage. The new life in the USSR will.

Gekht's columnist activity in multiple articles and sketches (ocherki) that appeared in Pravda and Izvestia on a regular basis throughout all of 1930s continuously emphasizes the differences between the Old and New Jews and the inevitability of the old traditional way of life to die and give way to a new Soviet Jew. As Harriet Murav demonstrated,

the genre of the sketches rose to prominence in the Soviet period for the purpose of informing the mass readership of everything that was being created. However, Gekht's sketch[es] on the old Jew show not what has been created but rather what was destroyed. The Jew appears to disappear; or he is made to disappear and in so doing to reappear ${ }^{33}$.

In the article What Once was a Shtetl, published in "Pravda" in 1936, Gekht expresses surprise that while visiting the small Jewish town of Litin he met no young people, only elders:

How happy I felt upon understanding that all the young people are gone. The shtetl is destroyed, the shtetl is dead, and I feel no sorrow for its death. Youth is in Moscow and Leningrad, youth is in Birobidzhan, youth is building factories and plants; youth is draining swamps in taiga and driving the first tractor on the Far Eastern fields. I suddenly called to mind a story of the Pied Piper who led all children out of the town of Hameln. Well... for our generation this Pied Piper was the revolution. We left and never looked back ${ }^{34}$.

Gekht employs a similar device in the novel. The narrator talks with Benjamin Brown about a recent trip to his native

\footnotetext{
32 B. Czerny, Le Voyageur et l'émigré..., p. 12.

33 H. Murav, Music from a Speeding Train..., p. 67.

34 С. Гехт, Бывшее местечко, "Правда", 03.05.1936.
} 
shtetl, and, just as in the aforementioned article, mentions that there are no young people left in the shtetl since "they all left for big cities where they work as laborers, engineers, tractor drivers and technicians ${ }^{\prime \prime 35}$. Gekht reinforces the importance of higher education in transforming the Jews, yet constantly omits mentioning middle-class professions such as teachers, writers, or doctors; and it is likely that he intentionally avoids professions that had traditionally signified a well-established Jew, while emphasizing the working, "proletarian" occupations that had not formerly been highly regarded by Jews. A tractor-driver, a pilot, or a mine worker symbolizes a new Soviet Jew, a liberated and regenerated Jew. At the same time, when Gordon discusses Palestine, he complains of the excess of lawyers, doctors, and dentists - the most popular Jewish professions in the old world. Similarly, Lazar Dayan, who hopes to attend the workers' evening university upon his return to the USSR, sees no future for any education advancement for newcomers in Palestine, expressing hatred and disrespect even for established cultural figures as Jabotinsky or Bialik. The description of the inaugural ceremony of the HUJl in narrators' words is reminiscent of a funeral procession with its stress on dryness, burn and death:

Сухой ветер пустыни засыпал людей пылью, пятнал и рвал парадные одежды с плеч. Мёртвые стояли горы, жалкие едва шелестели оливки по склонам, на горизонте маячил караван, - мертвая сожжённая страна безмолвствовала вокруг. И оттого не настоящим казалось затеянное - не настоящим, как декорации при дневном свете. И кто-то должен был за всё это ответить ${ }^{36}$.

Both novels deeply engage in discussing and presenting the nature of Palestine. It both works Palestine is presented as scarce and dry. As Gekht tells us, "the hills of Judea are dry and barren. They produce no oaks, neither cedars, nor palms. There is no tree around, just an accidental shrub like a bag of needles extends from a rock" ${ }^{\prime \prime 3}$. Egart's descriptions of Palestinian landscape share a constant feeling of dangerous intensity, an unhealthy neurotic atmosphere that largely corresponds to Gekht's negative presentation of Palestine as a barren land: "A pathetic piece of Moon is timidly climbing the steep black sky. A malarial mosquito is singing a sweet revenge. A sweet and rotten smell creeps from

\footnotetext{
35 С. Гехт, Пароход идёт в Яффу и обратно, Художественная литература, Москва 1936, р. 50.

36 М. Эгарт, Опалённая земля. ..., р. 313.

7 С. Гехт, Пароход идёт в Яффу и обратно..., р. 85.
} 
a swamp, a nauseous smell, as of an unclean wound"38. In both works the nature certainly does not exist per se, but is used to develop a social argument: in Palestinian swamps and sands man stands always in opposition to nature; he tries to conquer it like his enemy, yet all in vain. Gekht compares the landscape of Palestine to that of taiga, "a great kingdom of woods and mountains, an astonishment of mountain streams that create gorges and waterfalls; the quietness of the world, untouched by the civilization"139. He argues that in the Far East a city dweller can finally find a union with nature, becoming part of a great chain of being that will transform his old Jewish identity, whereas in Palestine is always has to oppose the wild.

It is very clear that both works use nature in an attempt to develop a social argument: Palestine has no future not because of its climate or its natural resources but due to its social structure. Just like the "old" capitalist world, Palestine is divided into the rich and the poor: the rich exploit the poor and do not care about them. Egart's secondary character, Ezra, compares the wealthy cafes of Tel Aviv to a door that hides a "Jewish truth" from those who seek it and causes doubts in those who had previously believed in the utopian nature of their motherland ${ }^{40}$. Gekht stresses that although some Jews had left for Palestine because of their Zionist aspirations, many immigrants had been "bourgeois" Jews who ran away from the revolution. On the ship that brought immigrants from Odessa to Palestine, "the rich Jews, suddenly void of their servants, did not care at all about their clean clothes or faces. Gordon was astonished at how dirty and smelly was the air around them and yet how arrogant they were to their underprivileged companions ${ }^{\prime \prime 4}$. Gekht presents the return to the Holy Land, the aliyah, in such a light that it loses its Zionist ideological essence and is downgraded to being just a small part of the whole body of White (anti-Bolshevik) emigration. In Egart's novel the parallel between the Zionists and the Whites is even stronger. In the first part of the novel, which is set during the Civil War, Gnilopol experiences a horrendous pogrom led by White Cossacks. Lazar's younger sister is raped during the pogrom and, in the aftermath, she commits suicide. Among the initiators of

38 М. Эгарт, Опалённая земля..., р. 313.

39 С. Гехт, Пароход идёт в Яффу и обратно..., р. 132, 45.

40 М. Эгарт, Опалённая земля..., р. 212.

${ }^{41}$ Ibidem, p. 137. It is worth noting that Gekht compares the steamboat to Jaffa to Noah's Ark, an image that also appears in Bulgakov's play On the Run (Бez), which is devoted to the subject of White emigration to the Middle East. 
the pogrom is a local Polish officer named Dennis Stativa. Lazar is stunned when he meets Dennis at a Jewish farm in Galilee. As it turns out, after traveling with White Army troops from the Crimea to Constantinople, Dennis wanders in the Middle East; he eventually migrates to Palestine where he is gladly welcomed in a Jewish settlement due to his good driving skills. He now drives a tractor, cultivates Jewish fields "still in the same blue army cap that he wore in Gnilopol"42, and abuses Arab peasants in just the same way as he abused Jews in Ukraine.

Both Gekht and Egart emphasized Palestine's complete dependence on England, a capitalist country that hates Bolshevism. As a result, the Jews in Palestine had to be anti-communist in order to please the English. Gekht very pessimistically discusses the Balfour Declaration that originally helped a lot of Odessa Jews to immigrate to Palestine after the revolution in search of a new life. He believes that the so-called "White Papers" — the later changes in British policy toward the Balfour declaration, which gradually and progressively closed the gates of Palestine to Jewish immigration and settlement - has cancelled the original declaration, and that without English support, Palestine has no future. Egart's narrator cites a popular Palestinian proverb that Palestine is a Jewish state, situated on Arab land, and ruled by the British.

The most important opposition between the Palestine and USSR for both Egart and Gekht is the "national question", that is, the relations between different ethnic groups. Both writers promote an idea that would later become the key postulate of Soviet antiIsraeli propaganda: Jews in Palestine are aggressors. Why Jews are aggressors is not totally clear, since in neither Gekht's nor Egart's work do they ever initiate any conflict; however, a statement by an Arab in Gekht's novel provides a possible answer: "Jewish aggression manifests itself not in a military conflict or a riot but simply in the fact that Jews have come here and want to live on our land! ${ }^{143}$ This statement resonates in a song perpetually sung by Arab peasants during their rest time in the fields in Egart's novel: "All Jews are dogs; and Palestine is our land... Allah will punish the Jews" ${ }^{144}$. Similarly, most Jews in both works stress that Arabs would be always hostile to Jews and Jews would never find a peaceful solution to stop the ethnic conflict. As one of Egart's characters says, quoting Zeev Jabotinsky, "in blood and fire Judea

\footnotetext{
42 М. Эгарт, Опалённая земля..., р. 72.

43 С. Гехт, Пароход идёт в Яфффу и обратно. ..., рр. 123-24.

44 М. Эгарт, Опалённая земля..., р. 65.
} 
died; in blood and fire it will be revived"45. Personal friendship with Arabs is not encouraged either. When Gordon tries to argue with his friend about a fellow Arab farmer, saying, "How can he be an enemy if he is my friend," he gets the following answer: "He cannot be your friend because he is our enemy." The reaction from the Arab side is the same. An Arab whom Gordon believes to be a friend comes to kill him in the middle of the night. When Gordon probes him for a reason, he shrieks emotionally: "Even if I like you, you took away my land"46.

As Weisskoph has noted, in the words of Ezra and the PCP party that he represents in the novel, the Zionist dream is replaced by the dream of the mutual solidarity of peasants and proletarians of all ethnicities, and eventually, probably by the dream of an Arab-Jewish multi-ethnic communist state ${ }^{47}$. Yet, even in this ideological interpretation, in spite of Ezra's best intentions, the final response of the old Fahmi does not sound very promising for Jews in Palestine: "We will beat the British. We will beat the Jews. We will sit on our land. Lenin has told us $\mathrm{so}^{\text {"148 }}$. It is clear from both novels that the return to the USSR seems to be the only successful option for the protagonists.

Geht argues that "the major problem that Jews face in Palestine is their inability to comprehend that even if this land once belonged to the Jews, many centuries have passed since then, and now there are other people who legally claim this land as theirs "49. He then contrasts Palestine with Birobidzhan, which he calls "a wild uninhabited land"50 where no one can complain that Jews annex or occupy somebody's land when they build their new state in the Far East. "National relations in Birobidzhan are healthy; not even one sore can ruin them because historically the land in the Far East belongs to no one, and, therefore, colonizing Jews would not be annexing anyone's possession" 51 .

While neither the first, nor the second, altered and published already in 1937, when the Birobidjan project was in full swing, edition of Scorched Land provides any reference to Jewish settlements on Far East, Egart also repeatedly implies that Bolshevik ethic relations are healthy by contrast with those of the Zionists, and that they root of the conflict lies in social structure of

45 Ibidem, p. 13.

46 С. Гехт, Пароход идёт в Яффу и обратно..., р. 124.

47 Ibidem, p. 7.

48 Ibidem.

49 Ibidem, p.142.

50 Ibidem, p. 119.

51 Ibidem. 
the Palestinian society. As Lazar Dayan and his communist friend Ezra believe, the answer to the Jewish - Arab conflict lies not in the issue of land but in that of exploitation. Jews in Palestine underpay Arabs; they prefer to hire Arabs rather than their own fellow Jews because they can pay them less. Ezra hopes to explain to the Arabs that it is not the Jews who take their land, but their own rich landowners, who have lost their estates as a result of their overspending and excessive luxury, and are now involuntary, forced to sell land to Jews:

Poor Jews and poor Arabs are brothers. The British are our mutual enemy. The poor have to stick together, in one misery as on one road. The rich Musa Jalil does nothing and lives lavishly. You plow, you fertilize the land, you harvest his grain; and he has sold his land, your land, to the Jews. The Jews chase you with a stick like jackals, but you keep silent. Comrade Lenin, maskubi Lenin, said, 'He who works the land, owns it'. 'Lenin, Lenin', the old Arab Fahmi whispers fiercely and passionately as I never heard him ever whisper anything 'Lenin said! We will ask them. I know, they will return the land's2.

Gekht's argument is, however, is rather disconcerting. The narrator tries to contrast the JAR to Palestine by saying that "historically the land in the Far East belongs to no one", and therefore colonizing Jews would not be annexing anyone's possession". Yet he continues his argument by claiming that "in the JAR no one can say that a newcomer wants to seize the land from the others. Koreans and Cossacks, who has long lived on those lands, are happily welcoming the arrival of Jews. The Jews come to them as friends, as enlightened neighbors, they bring machinery and electricity"53. Therefore, as the quote progresses, the reader suddenly realizes that the land is, in fact, inhabited, by Koreans and Cossacks, who, according to the narrator's argument, will be undoubtedly glad to embrace the enlightened newcomers who bring them machinery. The reader logically wonders how the Jewish settlers in the JAR differ from Palestinian Jews who bring unwelcome tractors to Arab fields ${ }^{54}$.

\footnotetext{
М. Эгарт, Опалённая земля..., р. 312.

53 Ibidem.

54 It is this part of Gekht's argument more than any other that presents him as a Soviet, not a Jewish writer, and at the same time where he subverts and contradicts himself. In fact, most of Gekht's articles throughout the 1930s have little to do with the Jews. He writes about irrigation in Turkmenistan and Uzbekistan, farm collectivization in Belorussia, and steel production in Siberia. All of these articles are characterized by the same style and ideology, which could be described as Soviet colonialism. Ethnic minorities in these articles are always depicted as backward nations that are developed and illuminated by Soviet industrial, agricultural, and educational policies; Gekht attempts to apply the same technique, the technique that he adopted as a Soviet journalist rather that a Jewish writer, to the ethic situation in the JAR.
} 
From the standpoint of the plot both novels are very similar in regards to the fact that although they both witness the protagonists' lives in Palestine and their ultimate decisions to return to Soviet Russia, both of them never continue further than placing their protagonists on the steamboat that returns "the lost tribe" back to their Soviet future. Egart's novel has an open ending: he leaves his protagonist on the open deck of the returning ship with a flowering red flag on its mast; Gekht hastens to add briefly that Gordon finds his happiness in Birobidzhan, yet never provides the reader with any further details, excusing himself by saying, "this is a different story that I would probably tell you another time ${ }^{\prime 55}$. Yet, in regards to the ideological task, these two novels are quite different. Egart's book has been most probably expressing the author's genuine disillusionment in Zionism yet lucky to be composed at the very correct ideological moment. It is a genuine autobiography, fictional by no doubt, but still largely personal. By contrast, Gekht's book has certainly been fulfilling an ideological initiative to present an opposition between the future if Palestine and that of the JAR and to promote the Jewish Autonomous Region among those Soviet Jews who might still possess Zionist aspirations. It is a typical socialist realist novel designed to create a mythologized fictional reality. A first person narration that shows the reader the life in JAR, paired with letters and diaries that the narrator receives from Alexander Gordon is intended to create a suggestion of intimacy between the narrator and the other characters, pushing the reader to trust the reliability of the narration. Gekht perpetually emphasizes the non-fictional accuracy of the addresses and names of people he mentions. However, a brief analysis proves that the facts he provides are mostly fraud. For example, Gekht spends a substantial amount of time describing life at the collective farm Voyo Novo, built, as he claims, exclusively by settlers from Palestine. No historical evidence supports the existence of such farm in the Russian Far East. However, there truly was such farm built by the settlers from Palestine in the 1920s in the Crimea; and in the late 1920s, after visiting the Jewish settlements there, Gekht devoted a small chapter of Efim Koluzhny to the description of everyday life at this farm $^{56}$. Clearly, Gekht simply invented the Palestinian collective farm in the JAR using the name and description of another colony that existed a few years earlier in a different region and, by the way, had already completely disintegrated by 1936, the year of the

\footnotetext{
55 С. Гехт, Пароход идёт в Яффуу и обратно..., р. 267.

56 RGALI, f. 2800, dd. 61, I.63.
} 
publication of The Steamboat Goes to Jaffa and Back. The reasons for such a falsification are fairly obvious. To prove his argument that the settlers from Palestine were able to find their happiness in Birobidzhan, Gekht needed factual evidence. Yet there was none to use. In contrast to the Crimean project, which indeed included a large number of settlers from Palestin, enough to build a separate farm, those few repatriates who had chosen to move to the JAR never created their own farms. Therefore, Gekht was left with only one option: to create a typical Socialist Realist pseudoreality, "a reality in its revolutionary development", a non-existent "Palestinian" farm in the Far East. Gekht must have recalled his trip to the Crimea and effortlessly transported the Voyo Novo settlement in time and place. The presence of a Palestinian collective farm in the JAR first of all allows the narrator to use its example to create an opposition between an agricultural collective farm in Palestine, the kibbutz, and a Soviet collective farm. While the members of kibbutz are lost in linguistic battles over Yiddish and Hebrew and over personal ideological preferences, the members of the Soviet collective farm devote their time to mutual productive work. Simultaneously, the name of the Soviet farm, The New Way, taken neither from Yiddish nor Hebrew but from Esperanto, emphasizes, in accordance with Soviet ideology, the universal, multi-ethic nature of the Jewish Autonomous Region, unlike Palestine, which is deeply engaged in ethnic conflicts. As a settler at Voyo Novo says: "We welcome everyone, Koreans, Cossacks, Jews... anyone who does not mind hard work" ${ }^{157}$.

It is worth noting that Gekht's narrative frequently and deliberately uses Zionist ideological clichés in application to the life in Birobidzhan to link the Soviet Jewish state to the Zionist tradition and thus to label the creation of the JAR as neoZionism. One of the images that constantly appear in the text is the image of this land as profound of "milk and honey". As one of the characters states, "soon the whole world will be eating honey only from the JAR. Even in Paris people will plead in stores, 'could you give me, please, a jar of Birobidzhan honey?!'58 As a result, Gekht's description of the JAR and its future can be characterized as an intersection of Soviet Socialist Realism and Jewish utopianism. Some details are so fantastic that they seem to be taken from a folktale: "the settlers have told the American journalists, 'We are picking the third harvest of beets and carrots!

\footnotetext{
С. Гехт, Пароход идёт в Яффу и обратно..., р. 155.

$58 \mathrm{Ibidem}, \mathrm{p}$. 135. Such policy was widespread in literature devoted to the promotion of the region and can, for example, be also seen in David Bergelson's Birobidzhaner.
} 
Our cucumbers are the sweetest in the whole USSR! Our cheese is the best in the country"59. The JAR of Gekht's novel is an imaginary land, a Paradise, a Garden of Eden. Yet, the author continuously rejects any claims of utopianism in his arguments. He constantly emphasizes that "while the plans for transforming Palestine are based on utopian enthusiasm, the construction of the JAR is founded on the planned economy and a five-year plan, on logic and reason and not on naïve idealistic ideology". As one of the protagonists observes, "Palestine is seriously ill, while Birobidzhan is healthy and young. We hoped that Palestine would give us our future, but it has not. Palestine is our Past, the JAR is our Future" ${ }^{160}$.

However, as much as Mark Egart and Semyon Gekht strive to prove themselves as loyal Soviet authors, in spite of all their attempts to reject Zionism, the reader cannot stop being mesmerized by their descriptions of Palestine, and, in the specific case of Gecht, being constantly bored by the chapters that describe the JAR. As much, for example, as Gekht and Egart try to present the country's nature in a negative light, it comes as a surprise that it is described so colorfully. Considering that Gekht never visited Palestine, his descriptions of it are extremely vivid and beautiful, and by contrast with abstract cliché descriptions of the nature of Russian Far East are also very detailed. In the place of amorphous Siberian mountains and waterfalls, we can easily visualize his descriptions of thorny cactus fences and smelly orange groves, black palm leaves in the wind, tired camels slowly walking along roads covered with white dust; the smell of rotten citrus; and bleak yellow fields extending to the shadowy horizon. Egart's descriptions of the Palestinian nature are even more sensual and tangible than Gekht's. The sun is compared to a lion's mane and its strength to a fierce bull, a road from Caesarea to Acre to "white bones of people long dead"61. The humid and rich smells of earth, the colors of grasses and flowers of Palestine are presented so physically vivid in Egart's text that the reader, in spite of all hatred that comes in the narrator's voice, is deeply touched by the beauty of the seemingly scorched and barren land. Upon finishing the book, the reader is left with a feeling that, regardless of the ideologically correct intentions, both the authors, being

59 Ibidem, p. 34.

60 Ibidem, p. 140. In reality, as American scholar Robert Weinberg has recently noted, there was no serious planning in JAR at all. In his words, "the colonization of Birobidzhan was begun and executed without preparation, planning and study. All the misfortunes are due to the hasty manner in which the Birobidzhan project was implemented". R. Weinberg, Stalin's Forgotten Zion..., p. 12.)

61 М. Эгарт, Опалённая земля. .., р. 4. 
suddenly and unpredictably allowed due to the ideological reasons to write a negative account of Jewish life in Palestine, rush to share the Zionist dreams of their youth, their lost hopes, their nostalgia for the land that one of them had never seen yet had always imagined, and that the other has abandoned and rejected but still intensely misses. And it is ironic that if the books discussed in this article have now any literary or historical value, it lies indeed in the fact that these are the only two Soviet mainstream novels that closely familiarize the reader with the life of Russian Jews in Palestine.

In the middle of the 1930s, neither Semeon Gekht nor Mark Egart knew anything about the future. Modern readers, by contrast, are well aware of what would follow. Palestine would become the state of Israel; of those settlers who repatriated to the USSR, most would be either executed by Soviet authorities, or murdered by Nazis, and in less than a decade the Soviet government would adopt a strong anti-Semitic ideology. We are aware of the Holocaust, the Doctor's Plot, the Six-Day War, and the struggle for aliyah. They were not. In the pamphlet Birobidzhan and Palestine, Isaak Sudarsky mentions the names of various small Zionist settlements. With numbers in hand he argues for the ultimate failure of these colonies, of Dganya and Petakh Tikva, of Rishon-le-Zion and Nahalal. All these places, small and large, are still proudly present on the map of contemporary Israel. In the contemporary reality of the present it could be easy to dismiss and forget Egart's and Gekht's books, which have already unreservedly fallen into oblivion. However, after all these years the questions that were raised in those novels still remain relevant: the question of Arab-Jewish relations in Israel, the question of aliyah and diaspora; and that of the initial disillusionments and diverse fates of immigrants. For the targeted readers of Stalinist Russia the task of these two writers was to dismiss Zionism and glorify the future of Jews in Russia. Yet for those readers who grew up in the anti-Semitic atmosphere of the last decades of the USSR, for those who took advantage of one-way tickets to Israel during the years of stagnation and perestoika, The Steamboat Goes to Jaffa and Back and The Scorched Land, despite their seemingly antiZionist nature, remain a tribute to the early Russian Zionists, to their hopes, aspirations, and disillusionments, and to the eternal question of whether there is a place on earth where a Wandering Jew can finally find his happiness and peace. 


\section{References}

Czerny, Boris. "Le Voyageur et l'émigré. Le motif de la sortie d'Egypte dans la littérature russe des années 1920-1930." Cahiers du Monde Russe, Vol. 52, No. 4, 2011: 529-553.

Dimanshteyn, Semyon. "Yevreyskaya avtonomnaya oblast' — detishche oktyabr'skoy revolyutsii." Revolyutsiya i natsional'nosti. Moscow, 1934 [Диманштейн, Семён. “Еврейская автономная область - детище октябрьской революции." Револючия и национальности. Москва, 1934].

Dotan, Shmuel, Adumim: Ha-Miflagah ha-komunistit be-Erets-Yisrael. Kefar-Saba: Shevna-ha-Sofer, 1991.

Dotan, Shmuel. Biroidzhan kealternativa le Erts Yisrael. Tel Aviv: Ha-Uma, 1993/4.

Egart, Mark. Opalyonnaya zemlya. Moscow: Khudozhestvennaya literatura, 1933 [Эгарт, Марк. Опалённая земля. Москва: Художественная литература, 1933].

Estraikh, Gennady; Krutikov, Mikhail (eds.). Yiddish and the Left. New York: Legenda, 2000.

Fink, Viktor. Evrei na zemle. Moscow: Gosud. Izdat., 1930 [Финк, Виктор. Евреи на земле. Москва: Госуд. Издат., 1930].

Gekht, Semyon. Parokhod idyot v Yaffu i obratno. Moscow: Khudozhestvennaya literatura, 1936 [Гехт, Семён. Пароход идёт в Яффру и обратно. Москва: Художественная литература, 1936].

Gessen, Masha. Where the Jews Aren't: The Sad and Absurd Story of Birobidzhan, Russia's Jewish Autonomous Region. New York: Schocken 2016.

Kagedan, Allan. Soviet Zion: The Quest for a Russian Jewish Homeland. New York: St. Martin's Press, 1994.

Kotlerman, Ber, B. (ed.). Mizrekh: Jewish Studies in the Far East. Frankfut am Main: Peter Lang, 2011.

Murav, Harriet. Music from a Speeding Train. Stanford: Stanford University Press, 2011.

Melekhov, Aleksandr. Birobidzhan - zemlya obetovannaya. Moscow: Text, 2009 [Мелехов, Александр. Биробиджан - земля обетованная. Москва: Текст, 2009].

Nosenko, Evgeniy (ed.). Izrail' glazami russkikh:kul'tura i identichnost'. Moscow: Natalis, 2008 [Носенко, Евгений (ред.). Израиль глазами русских: культура и идентичность. Москва: Наталис, 2008].

Shneer, David. Through Soviet Jewish Eyes: Photography, War, and the Holocaust. New Jersey: Rutgers University Press, 2010.

Shrayer, Maxim (ed.), Voices of Russian Jewish Literature. Boston: Academic Studies Press, 2018.

Shrayer, Maxim. "Mark Egart and the Legacy of His Soviet Novel about Halutzim," On the Jewish Street, no 1, 2011.

Sudarskiy, Isaak. Birobidzhan i Palestina. Tel Aviv: Atikot, 1972 [Сударский, Исаак. Биробиджан и Палестина. Tel Aviv: Atikot, 1972].

Waiskopf, Mikhail. "Krasnoye plat'itse: obraz geroini v anti-sionistskom romane Marka Egarta Opalennaya zemlya." Solnechnoe Spleteniye. 
Jerusalem, 2004/27 [Вайскопф, Михаил. “Красное Платьице. Образ героини в анти-сионистском романе Марка Эгарта Опалённая земля." Солнечное сплетение. Иерусалим, 2004/27].

Weinberg, Richard. Stalin's Forgotten Zion. Oakland: University of California Press, 1998. 